\title{
Heterotic affinity and combining ability of exotic maize inbred lines for resistance to aflatoxin accumulation
}

\author{
Silvestro Meseka $\mathbb{D} \cdot$ W. Paul Williams • Marilyn L. Warburton • \\ Robert L. Brown · Joao Augusto • Alejandro Ortega-Beltran • \\ Ranajit Bandyopadhyay $\cdot$ Abebe Menkir
}

Received: 4 February 2018/Accepted: 4 September 2018/Published online: 25 September 2018

(C) The Author(s) 2018

\begin{abstract}
Aflatoxin accumulation in maize (Zea mays L.) kernels is a serious economic and health problem that reduces grain quality and nutritional values and causes death to livestock and humans. Understanding the genetic parameters and heterotic responses of exotic maize inbred lines can facilitate their use for developing aflatoxin resistant parents of hybrids in Africa. This study was designed to (1) determine the heterotic affinities of aflatoxin resistant exotic lines, (2) identify exotic inbreds with good combining ability, and (3) determine the mode of inheritance of resistance to aflatoxin contamination in these lines. A line $\times$ tester mating design was used to
\end{abstract}

S. Meseka - J. Augusto - A. Ortega-Beltran .

R. Bandyopadhyay · A. Menkir

International Institute of Tropical Agriculture, PMB 5320,

Oyo Road, Ibadan, Nigeria

W. P. Williams · M. L. Warburton

Corn Host Plant Resistance Research Unit, United States Department of Agriculture/Agricultural Research Service, P.O. Box 9555, Mississippi State, MS 39762, USA

R. L. Brown

Food and Feed Safety Unit, Southern Regional Research

Center, U.S. Department of Agriculture, United States

Department of Agriculture, Agricultural Research

Service, New Orleans, LA 70124, USA

A. Menkir $(\bowtie)$

IITA Ltd, Carolyn House, 26 Dingwall Road,

Croydon CR9 3EE, UK

e-mail: a.menkir@cgiar.org determine combining ability of 12 yellow and 13 white inbreds and classify them into heterotic groups. The inbreds were crossed to two adapted testers representing two African heterotic groups and the resulting testcrosses along with hybrid checks were evaluated in separate trials at two locations for 2 years in Nigeria. General combining ability (GCA) effects were more important than specific combining ability effects for aflatoxin and grain yield. Among 15 exotic inbred lines having negative GCA effects for aflatoxin and 13 with positive GCA effects for grain yield, six combined the two desired traits. Five white and six yellow endosperm testcrosses were found to be good specific combiners for the two desired traits. The exotic lines with negative GCA effects for aflatoxin accumulation will be used as donor parents to develop backcross populations for generating new inbred lines with much higher levels of resistance to aflatoxin accumulation.

Keywords Aflatoxin resistant lines - Combining ability - Heterotic affinity · Exotic inbred lines . Line $x$ tester

\section{Introduction}

Aflatoxins are a group of naturally occurring, highly toxic and carcinogenic secondary metabolites produced by certain Aspergillus species when infecting 
several agricultural crops including maize, groundnut, and cottonseed. Amongst the various aflatoxin-producing species, A. flavus and A. parasiticus are the most common causal agents of contamination in animal feed, human food, and exportable grain (Brown et al. 1999). Crops containing aflatoxin concentrations above tolerance thresholds cannot be exported to premium markets resulting in losses of millions of dollars to growers, feed manufacturers and livestock industries (Charmley et al. 1995; Zain, 2011). Aflatoxin contamination of maize (Zea mays L.) is a serious pre- and post-harvest problem because aflatoxin-producing fungi may infect the crop prior to harvest and remain with it and produce aflatoxins throughout harvest and storage (Brown et al. 1995, 1999; Williams et al. 2008). Aflatoxin-producing fungi are widespread in tropical and sub-tropical maize growing regions where environmental conditions are highly conducive (Hennigen and Dick 1995) for both fungal growth and subsequent aflatoxin formation.

The health effects of maize contaminated with aflatoxin can be more serious in developing countries because a large proportion of the grain is used for human consumption and there is limited capacity to monitor the level of aflatoxin contamination in the grain (Widstrom 1996; Menkir et al. 2006). In addition, regulations to monitor and restrict consumption of contaminated commodities may be absent or poorly enforced across the developing world ( $\mathrm{Wu}$ 2004). The widespread exposure to aflatoxin throughout sub-Saharan Africa has been implicated in increased incidence of several diseases including acute aflatoxicosis, liver cancer and kwashiorkor (Miller 1996; Ramjee 1996; Liang et al. 2006), impaired child growth and death (Bankole et al. 2006; Gong et al. 2008; Matacic 2016). A relatively recent severe episode of human aflatoxin poisoning was reported in Kenya where a total of 317 cases of aflatoxicosis with fatality rate of $39 \%$ resulted from ingestion of contaminated maize-based foods (Lewis et al. 2005; Probst et al. 2007). In June 2016, 14 people died in the Dodoma region of Tanzania after consumption of maize contaminated with high aflatoxins levels (http://allafrica.com/stories/201607290685. html).

Several methods, including cultural practices, chemical control, and breeding for host-plant resistance have been proposed to minimize the severity of
Aspergillus ear rot and subsequent aflatoxin accumulation in maize kernels. Presently, cost effective approaches that farmers can use to reduce aflatoxin contamination in maize include host plant resistance, use of non-aflatoxin-producing strains of A. flavus as bio-control agents, and adequate post-harvest handling of grain. Considerable efforts have been made in identifying maize genotypes resistant to pre-harvest $A$. flavus infection and aflatoxin contamination (Brown et al. 1995; Menkir et al. 2006; Williams et al. 2015). Several studies (Scott and Zummo 1988; Betrán et al. 2006; Menkir et al. 2008; Williams et al. 2008; Brown et al. 2016) have identified maize germplasm with high levels of resistance to aflatoxin accumulation over a range of environments. However, most of these resistant sources lack desirable agronomic performance and adaptation to target areas (Gorman et al. 1992; Brown et al. 1999; Brooks et al. 2005; Warburton and Williams 2014). This prompts the need for the utilization of exotic $\times$ adapted backcrosses to develop maize inbred lines combining desirable agronomic traits with higher levels of resistance to both kernel rot and aflatoxin accumulation.

Maize breeders consider exotic germplasm as sources of novel alleles that can be introgressed into locally adapted material to confer resistance against biotic and abiotic stresses (Dhliwayo et al. 2009; Adebayo et al. 2017). Holland and Goodman (1995) found that resistance to grey leaf spot (GLS) in crosses of tropical $\times$ temperate maize lines exceeded that of the hybrid check. Menkir et al. (2008) registered six inbred lines with resistance to aflatoxin contamination derived from backcrosses involving tropical elite inbred lines with varying levels of resistance to aflatoxin accumulation as recipients and inbred lines from the US with proven resistance to aflatoxin contamination as donors. These lines had aflatoxin levels lower than that of the elite tropical recipient parents or the donor temperate parents (Menkir et al. 2006). These results highlight the potential for exotic maize germplasm to improve the level of resistance to aflatoxin accumulation in lines adapted to the lowland tropics of West and Central Africa (WCA).

Combining ability is an effective tool for generating useful basic genetic information for the choice of parents and their performance in a series of crosses (Sprague and Tatum 1942). The mode of inheritance of resistance to aflatoxin accumulation in maize is complex, ranging from primarily additive (Darrah 
et al. 1987; Gardner et al. 1987; Liang et al. 2006) to non-additive (Gardner et al. 1987; Gorman et al. 1992; Campbell et al. 1997; Busboom and White 2004). The genetic background and environment play a large part in determining the mode of inheritance of resistance to aflatoxin, and this information is needed for the development of productive aflatoxin resistant hybrids and synthetics.

Over the years, scientists from the United States Department of Agriculture, Agricultural Research Service (USDA-ARS) and the International Institute of Tropical Agriculture (IITA) have exchanged maize inbred lines from diverse sources to successfully access novel alleles to improve adapted maize for resistance to aflatoxin accumulation (Menkir et al. 2008; Warburton and Williams 2014; Williams et al. 2015). The continual expansion of the genetic basis of aflatoxin resistant adapted germplasm through further exploitation of new and diverse exotic source germplasm is still needed to develop new and better aflatoxin resistant lines. Several white and yellow endosperm maize inbred lines with known resistance to aflatoxin accumulation identified by Warburton and Williams (2014) were then introduced from USDAARS to IITA. Effective use of these exotic lines in IITA's breeding program requires strategic introgression without disrupting the existing heterotic patterns of the adapted maize inbred lines (Menkir et al. 2006; Nelson and Goodman 2008). Consequently, assessment of the combining ability and the heterotic affinities of the exotic lines are essential for their optimal exploitation as donor parents (Pollak et al. 1991; Santos and Miranda Filho 1992; Eschandi and Hallauer 1996) to develop new and productive inbred lines with much higher levels of resistance to aflatoxin accumulation. Nelson and Goodman (2008) proposed the use of adapted testers for classifying exotic inbred lines into heterotic groups. Line $\times$ tester crosses can then be used to identify new aflatoxin resistant lines with specific combining ability (Menkir et al. 2003; Xia et al. 2005) and well defined heterotic affinities for effective introgression of novel aflatoxin resistance alleles into adapted aflatoxin resistant maize inbred lines. In the present study, 13 white and 12 yellow endosperm maize inbred lines were evaluated using line $\times$ tester design to: (1) determine the heterotic affinities of aflatoxin resistant exotic lines, (2) identify exotic inbred lines with good combining ability, and
(3) determine the mode of inheritance of resistance to aflatoxin contamination in these lines.

\section{Materials and methods}

Genetic materials

Twelve yellow and 13 white endosperm aflatoxin resistant maize inbred lines, originating from different sources, identified in Warburton and Williams (2014) were used for this study (Table 1). The seed for initiating this study was supplied by USDA-ARS' Corn Host Plant Resistance Research Unit (CHPRRU). These lines were crossed with two locally adapted aflatoxin resistant lines per color group, representing complementary African heterotic groups using a line $x$ tester mating design to generate a total of 24 yellow and 26 white testcrosses. Two commercial hybrids, Oba Super 1 (white) and Oba Super 2 (yellow), marketed by Premier Seeds Company in Nigeria, were included as checks.

\section{Design and layout of field trials}

The testcrosses representing each of the two endosperm colors along with a check hybrid were included in independent field trials and evaluated at Ibadan $\left(7^{\circ} 30^{\prime} \mathrm{N}, 3^{\circ} 54^{\prime} \mathrm{E}\right.$, altitude $\left.190 \mathrm{~m}\right)$ and Ikenne $\left(6^{\circ} 54^{\prime} \mathrm{N}\right.$, $3^{\circ} 42^{\prime} \mathrm{E}$, altitude $60 \mathrm{~m}$ ) in Nigeria during the main rainy seasons of 2014 and 2015 . The testcrosses in the first trial were arranged in a $5 \times 5$ alpha lattice design, whereas those in the second trial were arranged in a $9 \times 3$ alpha lattice design, each with two replications. Each testcross in each trial was planted in a $5 \mathrm{~m}$ row plot spaced $0.75 \mathrm{~m}$ apart with $0.50 \mathrm{~m}$ spacing between plants within a row. Three seeds were planted in a hill and thinned to two plants after emergence to attain a population density of 53,000 plants $\mathrm{ha}^{-1}$ in each trial. A compound fertilizer was applied at the rates of $60 \mathrm{~kg} \mathrm{~N}, 60 \mathrm{~kg} \mathrm{P}$, and $60 \mathrm{~kg} \mathrm{~K} \mathrm{ha}^{-1}$ at the time of sowing. An additional $60 \mathrm{~kg} \mathrm{~N} h a^{-1}$ was applied as top dressing 4 weeks later. In the two trials, gramoxone and atrazine were applied as pre-emergence herbicides at the rates of $1.5 \mathrm{~L}(\mathrm{~L})$ gramoxone and $2.5 \mathrm{~L}$ atrazine in $200 \mathrm{~L}$ of water per hectare. Subsequent manual weeding was done to keep the trials weed free. 
Table 1 Thirteen white and 12 yellow endosperm exotic maize inbred lines along with two adapted testers each, adaptation and their origin evaluated in testcrosses at Ibadan and Ikenne in Nigeria in 2014

CHPRRU, Corn Host Plant Resistance Research Unit; CIMMYT, International Maize and Wheat Improvement Center; IITA, International Institute of Tropical Agriculture; PISAmes, Plant Introduction Station in Ames; NCSU, North Carolina State University and 2015

\begin{tabular}{lllllll}
\hline No & White inbred & Adaptation & Origin & Yellow inbred & Adaptation & Origin \\
\hline 1 & CML108 & Exotic & CIMMYT & A6 & Exotic & CHPRRU \\
2 & CML11 & Exotic & CIMMYT & CML287 & Exotic & CIMMYT \\
3 & CML158Q & Exotic & CIMMYT & CML348 & Exotic & CIMMYT \\
4 & CML176 & Exotic & CIMMYT & Hi27 & Exotic & CHPRRU \\
5 & CML247 & Exotic & CIMMYT & Ki3 & Exotic & CHPRRU \\
6 & CML264 & Exotic & CIMMYT & Mp420 & Exotic & CHPRRU \\
7 & CML311 & Exotic & CIMMYT & Mp705 & Exotic & CHPRRU \\
8 & CML322 & Exotic & CIMMYT & Mp715 & Exotic & CHPRRU \\
9 & CML343 & Exotic & CIMMYT & Mp717 & Exotic & CHPRRU \\
10 & CML45 & Exotic & CIMMYT & Mp719 & Exotic & CHPRRU \\
11 & CML5 & Exotic & CIMMYT & NC289 & Exotic & CHPRRU \\
12 & Mp711 & Exotic & CHPRRU & NC334 & Exotic & CHPRRU \\
13 & Tzi8 & Adapted & IITA & IITATZI1383 & Tester & IITA \\
14 & IITATZI1191 & Tester & IITA & IITATZI1394 & Tester & IITA \\
15 & IITATZI1408 & Tester & IITA & Oba Super 2 & Check & Premier Seeds \\
16 & Oba Super 1 & Check & Premier Seeds & & & \\
\hline
\end{tabular}

Inoculation of the trials with a toxigenic strain of Aspergillus flavus

The trials were inoculated with a highly toxigenic $A$. flavus isolate ( $\mathrm{La}$ 3228), previously isolated from maize in Nigeria, 2-3 weeks before maize flowering. La 3228 produces large quantities of aflatoxin in maize and is frequently used in maize resistance breeding and toxigenicity studies at IITA (Atehnkeng et al. 2008a). The inoculation method consisted of broadcasting roasted, sterile sorghum grains coated with spores of $\mathrm{La} 3228\left(1.6 \times 10^{5}\right.$ conidia $\left.\mathrm{g}^{-1}\right)$. This inoculation method is employed in biological control strategies to limit aflatoxin accumulation by broadcasting products carrying atoxigenic isolates of $A$. flavus to competitively displace aflatoxin-producing fungi (Bandyopadhyay et al. 2016). The application rate was $100 \mathrm{~kg}$ of La 3228 coated sorghum grain per hectare. After application, the La 3228 germinating spores on sorghum grains are dispersed by wind and insects to pollen sacs, pollen grains, and silks, until reaching maize ears. This inoculation method ensures that $>80 \%$ of the fungi infecting the maize crop belong to the applied toxigenic La 3228 strain (Atehnkeng et al. 2016; Bandyopadhyay et al. 2016). The A. flavus toxigenic strains produce a large array of extracellular hydrolases to access nutrients that allow both fungal reproduction and aflatoxin formation (Mellon et al. 2007). The success of both fungal reproduction and aflatoxin formation is determined by the resistance mechanisms of the maize germplasm exposed to the toxigenic fungi.

\section{Laboratory analyses for aflatoxin content}

Ears of maize were shelled manually and then blended using a laboratory blender (Model 7011 HG, Waring Commercial, Springfield, MO) for $30 \mathrm{~s}$ in a $110 \mathrm{~mL}$ stainless steel blending jar (MC-2). Ground maize samples were stored at $4{ }^{\circ} \mathrm{C}$ before aflatoxin quantification. The blending jar was rinsed between samples with $80 \%$ ethanol to prevent cross contamination of aflatoxins. Aflatoxins were extracted from maize by mixing $100 \mathrm{~mL} 70 \%$ methanol with $20 \mathrm{~g}$ of ground sample (Atehnkeng et al. 2008b). The resulting suspensions were then shaken on a Roto-Shake Genie (Scientific Industries, Bohemia, NY) for $30 \mathrm{~min}$ at $400 \mathrm{rpm}$ and filtered through Whatman No. 1 filter paper (Whatman International Ltd., Maidstone, England). Filtrates were transferred to $250 \mathrm{~mL}$ separatory funnels and $100 \mathrm{~mL}$ distilled water were added to the funnels. The suspensions were extracted twice with $25 \mathrm{~mL}$ methylene chloride and the resulting methylene chloride phase was filtered through a bed of $25 \mathrm{~g}$ anhydrous sodium sulphate contained in fluted Whatman No. 4 filter paper, combined, and evaporated to dryness overnight in a chemical fume hood (Cotty and Cardwell 1999). The following day, residues were 
dissolved in $1 \mathrm{~mL}$ methylene chloride and directly spotted $(4 \mu \mathrm{L})$ alongside aflatoxin standards (Supelco, Bellefonte, PA) on thin layer chromatography (TLC) Aluminium $(20 \times 10 \mathrm{~cm})$ Silica gel $60 \mathrm{~F}_{254}$ plates (Merck, Darmstadt, Germany). Spotted plates were developed with a solvent solution (diethyl ethermethanol-water; 96:3:1) (Atehnkeng et al. 2016) and visualized under ultraviolet light $(365 \mathrm{~nm})$ to determine the presence or absence of aflatoxins. Aflatoxins were then quantified directly on TLC plates with a scanning densitometer (CAMAG TLC Scanner 3) and quantification software (winCATS 1.4.2, Camag, AG, Muttenz, Switzerland).

\section{Agronomic traits}

In each year, the severity of foliar diseases including Southern corn leaf blight (caused by Bipolaris maydis), Southern corn rust (caused by Puccinia polysora) and maize streak virus (MSV) were rated at each location in each plot on a scale of 1-5, where $1=$ no disease and $5=$ severe disease (blight, rust or streak) symptoms with $>75 \%$ leaf surface diseased. Days to anthesis and silking were recorded as the number of days from planting to when $50 \%$ of the plants in a plot had shed pollen and emerged silks, respectively. Plant and ear heights were measured in centimeters as the distance from the base of the plant to the height of the first tassel branch and the node bearing the upper ear, respectively. Plant aspect was rated on a scale of 1-5, where $1=$ excellent overall phenotypic appeal and $5=$ poor overall phenotypic appeal. Similarly, ear aspect was scored on a scale of $1-5$, where $1=$ clean, uniform, large, and well-filled ears and $5=$ rotten, variable, and small ears. All ears harvested from each plot were weighed, and representative samples of the ears were shelled to determine moisture content. Grain yield adjusted to $15 \%$ moisture was computed from ear weighed and grain moisture assuming a shelling percentage of $80 \%$.

\section{Statistical analyses}

Data for aflatoxin concentration in the samples was transformed $[\operatorname{Ln}(\mathrm{Y}+1)$, where $\mathrm{Y}$ indicates aflatoxin concentration $\left.\left(\mathrm{ng} \mathrm{g}^{-1}\right)\right]$ prior to statistical analysis. Each location-year combination was considered as a test environment. Analyses of variance (ANOVA) were computed for each site-year combination to generate entry means adjusted for block means according to the lattice design (Cochran and Cox 1960). Data for each location was analyzed separately and then combined analysis over environments was computed. In the combined analyses, environments were treated as random effects and testcrosses as fixed effects in the linear model. Mean square of variance was computed for line, tester and their interaction effects. The variances for line, tester and testcrosses were tested against their respective interactions with environment, and the interaction with environment term were tested against the pooled error. All analyses were carried out with PROC GLM in SAS (SAS Institute 2010) using a RANDOM statement with TEST option. To estimate GCA and SCA effects for aflatoxin accumulation and grain yield which were the main traits of interest for the testcrosses, further analyses were done according line $\times$ tester design as suggested by Singh and Chaudhary (1985) to partition the mean square due to testcrosses into GCA for line and tester, and SCA effects using SAS software program. The significance of GCA and SCA effects were tested by dividing the corresponding GCA and SCA values by their respective standard error and comparing the calculated $t$ with tabular $-t$ values at their corresponding error degree of freedom.

\section{Results}

Agronomic performance of testcrosses of white exotic inbred lines

In the combined analyses of variance, environment had significant effects on all measured traits. The variations for GCA among 13 white inbred lines were significant $(P<0.01-0.001)$ for most of the measured traits (Table 2). The two testers also varied significantly for days to silking, plant aspect and the three foliar diseases (leaf blight, rust and MSV) prevalent in the rainy forestry agroecology in Nigeria. The line $x$ tester interaction (SCA) was significant for aflatoxin accumulation, grain yield, days to silking, ear aspect and leaf rust scores. The ratio of GCA sum of squares was greater than SCA sum of squares for aflatoxin accumulation, grain yield, and most of the measured traits (data not shown). Mean squares for line $\times$ environment interaction were significant for aflatoxin accumulation, days to silking, and MSV, whereas the 
Table 2 Mean sum of squares from the combined analysis of variance for 13 white endosperm exotic inbred lines evaluated in testcrosses with two testers at Ikenne and Ibadan in 2014 and 2015

\begin{tabular}{|c|c|c|c|c|c|c|c|c|c|}
\hline Source & $D F$ & $\begin{array}{l}\text { Aflatoxin } \\
\left(\mathrm{ng} \mathrm{g}^{-1}\right)\end{array}$ & $\begin{array}{l}\text { Grain yield } \\
\left(\mathrm{kg} \mathrm{ha}^{-1}\right)\end{array}$ & $\begin{array}{l}\text { Silking } \\
\text { (day) }\end{array}$ & $\begin{array}{l}\text { Ear aspect } \\
(1-5)^{\mathrm{a}}\end{array}$ & $\begin{array}{l}\text { Plant } \\
\text { aspect } \\
(1-5)^{\mathrm{b}}\end{array}$ & $\begin{array}{l}\text { Rust } \\
(1-5)^{\mathrm{c}}\end{array}$ & $\begin{array}{l}\text { Streak } \\
(1-5)^{\mathrm{d}}\end{array}$ & $\begin{array}{l}\text { Blight } \\
(1-5)^{\mathrm{e}}\end{array}$ \\
\hline Environment (E) & 3 & $26,552.26 * * *$ & $45,286,219.50 * * *$ & $35.87 * * *$ & $11.22 * * *$ & $7.15 * * *$ & $1.28 * * *$ & $20.80 * * *$ & $2.41 * * *$ \\
\hline Line & 12 & $3938.13 * * *$ & $7,883,972.10 * *$ & $17.13 * * *$ & $0.95 * * *$ & $0.96 * * *$ & $0.29 * *$ & $0.32 * * *$ & 0.22 \\
\hline Tester & 1 & 48.27 & $59,034.90$ & $3.68 *$ & 0.13 & $2.64 * *$ & $1.16^{* *}$ & $0.74 * *$ & $2.95 * * *$ \\
\hline Line $\times$ tester & 12 & $5042.60 * * *$ & $2,518,429.30^{*}$ & $2.20 * *$ & $0.44 * *$ & 0.22 & $0.18^{*}$ & 0.08 & 0.14 \\
\hline Line $\times \mathrm{E}$ & 36 & $1356.40 *$ & $1,102,373.80$ & $1.36^{*}$ & 0.23 & 0.21 & 0.11 & $0.13 *$ & 0.13 \\
\hline Tester $\times E$ & 13 & 0.04 & $746,273.00$ & 1.15 & $0.82 * *$ & 0.19 & 0.20 & $0.22 *$ & 0.24 \\
\hline Line $\times$ tester $\times \mathrm{E}$ & 36 & $1790.74 * *$ & $1,838,446.00^{*}$ & 1.19 & $0.35^{* *}$ & 0.18 & 0.07 & 0.07 & 0.13 \\
\hline Pooled error & 72 & 708.82 & $803,367.15$ & 0.81 & 0.17 & 0.19 & 0.09 & 0.08 & 0.12 \\
\hline
\end{tabular}

$*, * *, * * *$ Significant at $0.05,0.01$ and 0.001 probability levels, respectively

${ }^{\mathrm{a}}$ Ear aspect visual scores on scale of $1-5$, where $1=$ clean uniformly filled ears and $5=$ poorly filled ear with signs of rot

${ }^{\mathrm{b}}$ Plant aspect, scored on scale of $1-5$, where $1=\operatorname{good}$ phenotypic appeal and $5=$ poor phenotypic appeal

${ }^{\mathrm{c}}$ Southern corn rust scored on scale of $1-5$, where $1=$ no rust and $5=$ severe rust

${ }^{\mathrm{d}}$ Streak virus scored on scale of $1-5$, where $1=$ highly resistant to streak and $5=$ highly susceptible to streak

${ }^{\mathrm{e}}$ Southern corn leaf blight scored on scale of $1-5$, where $1=$ no blight and $5=$ severe blight

tester $\times$ environment interaction was significant only for ear aspect score and MSV. Line $\times$ tester $\times$ environment interaction mean squares were significant for aflatoxin accumulation, grain yield, and ear aspect score (Table 2). Mean aflatoxin accumulation of testcrosses averaged across four environments varied from $4 \mathrm{ng} \mathrm{g}^{-1}$ for $\mathrm{Mp711} \times$ IITATZI1191 to $1011 \mathrm{ng} \mathrm{g}^{-1}$ for CML247 $\times$ IITATZI1191 producing grain yields of $2026 \mathrm{~kg} \mathrm{ha}^{-1}$ and $5331 \mathrm{~kg} \mathrm{ha}^{-1}$, respectively. Mean grain yield of the testcrosses ranged from $2026 \mathrm{~kg} \mathrm{ha}^{-1}$ for Mp711 $\times$ IITATZI1191 to $6367 \mathrm{~kg} \mathrm{ha}^{-1}$ for CML343 $\times$ IITATZI1408. Testcrosses of the tester IITATZI1191 accumulated $48 \%$ more aflatoxin than those of the tester IITATZI1408 (Table 3).

Among the 13 white inbred lines, eight had negative GCA effects for aflatoxin accumulation with two lines, (CML176 and Mp711), showing significant negative GCA effects. Seven of these lines also had positive GCA effects for grain yield, and four of these effects were significant (Table 4). However, four inbred lines (CML158Q, CML247, CML264, and CML45) had significant positive GCA effects for both aflatoxin accumulation and grain yield. Among the 26 testcrosses, 13 involving CML108, CML158Q, CML311, CML343, CML322, Mp711 with tester
IITATZI1191 and CML11, CML176, CML247, CML264, CML45, CML5 and TZi8 with IITATZI1408 tester had negative SCA effects for aflatoxin accumulation, six of these effects were significant (Table 3). Whereas 13 testcrosses involving CML108, CML158Q, CML247, CML264, CML322, CML45, CML5, and Tzi8 with tester IITATZI1191 and CML11, CML176, CML311, CML343, and Mp711 with IITATZI1408 had positive SCA effects for grain yield and eight of the effects were significant. We found three lines (CML11, CML5, and CML343) exhibiting negative GCA effects for aflatoxin accumulation that also had positive GCA effects for grain yield (Tables 3, 4). Five testcrosses (CML108 $\times$ IITATZI1191, CML322 $\times$ IITATZI1191, CML158Q $\times$ IITATZI1191, CML11 $\times$ IITATZI1408 and CML176 $\times$ IITATZI1408) had negative SCA effects for aflatoxin accumulation and positive SCA effects for grain yield (Tables 3, 4).

Heterotic affinities of 13 exotic inbred lines

The combining ability effects of grain yield of the 13 white aflatoxin resistant inbred lines in combination with the two adapted aflatoxin resistant testers were 
Table 3 Estimates of general combining ability (GCA) and specific combing ability (SCA) effects of 13 white endosperm exotic maize inbred lines for aflatoxin accumulation average for 2 years across Ikenne and Ibadan

\begin{tabular}{|c|c|c|c|c|c|}
\hline \multirow[t]{2}{*}{ Line } & \multicolumn{2}{|c|}{ Aflatoxin $\operatorname{Ln}^{\mathrm{a}}(\mathrm{y}+1)$ with } & \multirow[t]{2}{*}{ GCA } & \multicolumn{2}{|l|}{ SCA with } \\
\hline & IITATZI1191 & IITATZI1408 & & IITATZI1191 & IITATZI1408 \\
\hline CML108 & 3.08 & 3.78 & -0.44 & -0.43 & 0.432 \\
\hline CML11 & 4.74 & 2.29 & -0.36 & $1.14 * *$ & $-1.14^{* *}$ \\
\hline CML158Q & 5.01 & 5.05 & $1.15^{* * *}$ & -0.08 & 0.08 \\
\hline CML176 & 3.43 & 2.28 & $-1.02 * * *$ & 0.49 & -0.49 \\
\hline CML247 & 6.90 & 4.53 & $0.85 * *$ & 0.11 & -0.11 \\
\hline CML264 & 4.74 & 4.19 & $0.60 *$ & 0.19 & -0.19 \\
\hline CML311 & 3.25 & 3.96 & -0.26 & -0.44 & 0.44 \\
\hline CML322 & 3.95 & 4.08 & 0.15 & -0.15 & 0.15 \\
\hline CML343 & 3.63 & 3.81 & -0.16 & -0.18 & 0.18 \\
\hline CML45 & 4.89 & 4.43 & $0.78 * *$ & 0.15 & -0.15 \\
\hline CML5 & 4.49 & 3.05 & -0.10 & $0.64 *$ & $-0.64 *$ \\
\hline Mp711 & 1.34 & 4.10 & $-1.15^{* * *}$ & $-1.46^{* *}$ & $1.46^{* *}$ \\
\hline Tzi8 & 3.93 & 3.73 & -0.04 & 0.02 & -0.02 \\
\hline Mean & 4.11 & 3.79 & 0.0 & 0.0 & 0.0 \\
\hline LSD & 2.83 & 1.74 & 0.46 & 0.63 & 0.63 \\
\hline
\end{tabular}

$*, * *, * * *$ Significant at $0.05,0.01$ and 0.001 probability levels, respectively

${ }^{a}$ Plot means for aflatoxin concentration were transformed $\left(\mathrm{Ln}[\mathrm{y}+1]\right.$, where $\mathrm{y}=$ concentration of aflatoxin $\mathrm{ng} \mathrm{g}^{-1}$ in a sample) before statistical analysis

Table 4 Estimates of general combining ability (GCA) and specific combing ability (SCA) effects of 13 white endosperm exotic maize inbred lines for grain yield average for 2 years across Ikenne and Ibadan

\begin{tabular}{|c|c|c|c|c|c|c|}
\hline \multirow[t]{2}{*}{ Line } & \multicolumn{2}{|c|}{ Grain yield $\left(\mathrm{kg} \mathrm{ha}^{-1}\right)$ with } & \multirow[t]{2}{*}{ GCA } & \multicolumn{2}{|l|}{ SCA with } & \multirow[t]{2}{*}{ Heterotic group } \\
\hline & IITATZI1191 & IITATZI1408 & & IITATZI1191 & IITATZI1408 & \\
\hline CML108 & 3610 & 3435 & $-1072 * * *$ & 215 & -215 & IITATZI1408 \\
\hline CML11 & 4751 & 5890 & $726^{* *}$ & -442 & 442 & IITATZI1191 \\
\hline CML158Q & 4958 & 4823 & 296 & 195 & -195 & IITATZI1408 \\
\hline CML176 & 4326 & 4823 & -20 & -121 & 121 & IITATZI1191 \\
\hline CML247 & 5331 & 4804 & 473 & 390 & -390 & IITATZI1408 \\
\hline CML264 & 5225 & 5237 & $637^{*}$ & 121 & -121 & IITATZI1408 \\
\hline CML311 & 3971 & 4390 & -414 & -82 & 82 & IITATZI1191 \\
\hline CML322 & 3989 & 3727 & $-736^{* *}$ & 259 & -259 & IITATZI1408 \\
\hline CML343 & 4598 & 6367 & $888^{* *}$ & $-757 * *$ & $757 * *$ & IITATZI1191 \\
\hline CML45 & 4961 & 5157 & 464 & 30 & -29.6 & IITATZI1408 \\
\hline CML5 & 5749 & 4931 & $746^{* *}$ & $536^{*}$ & $-536^{*}$ & IITATZI1408 \\
\hline Mp711 & 2026 & 3970 & $-1596^{* * *}$ & $-844 * *$ & $844 * *$ & IITATZI1191 \\
\hline Tzi8 & 4577 & 3828 & -392 & $502 *$ & $-502 *$ & IITATZI1408 \\
\hline Mean & 4467.1 & 4721.7 & 0.0 & 0.0 & 0.0 & \\
\hline LSD & 2062.0 & 1857.2 & 443.4 & 392.0 & 392.0 & \\
\hline
\end{tabular}

$*, * *, * * *$ Significant at $0.05,0.01$ and 0.001 probability levels, respectively 
used as the basis for classifying the exotic lines into heterotic groups. Eight introduced inbred lines showing positive SCA effects with IITATZI1191 and negative SCA effects with IITATZI1408 were placed into the IITATZI1408 heterotic group (Table 4). Five inbred lines exhibiting positive SCA effects with IITATZI1408 and negative SCA effects with IITATZI1191 were placed into the IITATZI1191 heterotic group (Table 4).

Agronomic performance of testcrosses of yellow exotic inbred lines

In the combined analyses of variance across four environments, environment had highly significant $(P<0.001)$ effects on aflatoxin accumulation and most other traits measured in this study (Table 5). The variations among the 12 lines (GCA) were highly significant for aflatoxin accumulation, grain yield and most other traits. The two testers (GCA) also showed significant differences in aflatoxin accumulation, grain yield, ear aspect, plant aspect, MSV and leaf blight scores. Line $\times$ tester interaction (SCA) was significant for grain yield, days to silking, and plant aspect scores (Table 5). The ratio of GCA sum of squares was greater than SCA sum of squares for aflatoxin accumulation, grain yield, days to silking, plant aspect, leaf rust, MSV and leaf blight (data not shown). Line $x$ environment interaction was significant for grain yield, days to silking, MSV, and leaf blight, whereas tester $\times$ environment and line $\times$ tester $\times$ environment interactions were not significant for aflatoxin accumulation and most other traits (Table 5). Mean aflatoxin accumulation of the 24 testcrosses averaged across the four environments varied from $8 \mathrm{ng} \mathrm{g}^{-1}$ for Mp420 $\times$ IITATZI1394 to $508 \mathrm{ng} \mathrm{g}^{-1}$ for Ki3 $\times$ IITATZI1383 producing grain yields of $1530 \mathrm{~kg} \mathrm{ha}^{-1}$ and $3740 \mathrm{~kg} \mathrm{ha}^{-1}$, respectively. The mean grain yield of testcrosses varied from $1530 \mathrm{~kg} \mathrm{ha}^{-1}$ for Mp420 $\times$ IITATZI1384 to $4405 \mathrm{~kg} \mathrm{ha}^{-1}$ for A6 $\times$ IITATZI1394. Testcrosses of the tester IITATZI1394 accumulated $45 \%$ less aflatoxin and produced $10 \%$ more grain yield than testcrosses of the tester IITATZI1383.

Among the 12 lines, Hi27, Mp420, Mp717 and NC334 had significant negative GCA effect for aflatoxin accumulation (Table 6), whereas CML287, CML348, NC334 and Ki3 had significant positive GCA effect for grain yield (Table 7). Inbreds A6, CML348 and Mp705 had non-significant positive GCA effects for aflatoxin production and significant or non-significant positive or negative GCA effects for

Table 5 Mean sum of squares from the combined analysis of variance for 12 yellow endosperm exotic maize inbred lines evaluated in testcrosses with two testers for aflatoxin resistance at Ikenne and Ibadan in 2014 and 2015

\begin{tabular}{|c|c|c|c|c|c|c|c|c|c|}
\hline Source & $D F$ & $\begin{array}{l}\text { Aflatoxin } \\
\left(n g g^{-1}\right)\end{array}$ & $\begin{array}{l}\text { Grain yield } \\
\left(\mathrm{kg} \mathrm{ha}^{-1}\right)\end{array}$ & $\begin{array}{l}\text { Silking } \\
\text { (day) }\end{array}$ & $\begin{array}{l}\text { Ear aspect } \\
(1-5)^{\mathrm{a}}\end{array}$ & $\begin{array}{l}\text { Plant } \\
\text { aspect } \\
(1-5)^{b}\end{array}$ & $\begin{array}{l}\text { Rust } \\
(1-5)^{\mathrm{c}}\end{array}$ & $\begin{array}{l}\text { Streak } \\
(1-5)^{\mathrm{d}}\end{array}$ & $\begin{array}{l}\text { Blight } \\
(1-5)^{\mathrm{e}}\end{array}$ \\
\hline Environment (E) & 3 & $8668.20 * *$ & $54,381,668.80 * * *$ & $411.31 * * *$ & $13.08 * * *$ & $5.97 * * *$ & $2.71 * * *$ & $18.92 * * *$ & $19.47 * * *$ \\
\hline Line & 11 & $1506.70^{*}$ & $8,331,112.70 * * *$ & $34.51 * * *$ & 0.44 & $1.59 * * *$ & $0.49 * *$ & $0.42 * *$ & $0.46 * * *$ \\
\hline Tester & 1 & $1732.60 *$ & $44,421,675.70 * * *$ & 3.37 & $3.37 * *$ & $1.14 *$ & 0.15 & $0.94 * *$ & $0.50 *$ \\
\hline Line $\times$ tester & 11 & 1007.43 & $2,306,143.70 * *$ & $7.84 *$ & 0.60 & $0.56^{*}$ & 0.16 & 0.20 & 0.15 \\
\hline Line $\times \mathrm{E}$ & 33 & 1288.62 & $2,083,527.10 * * *$ & $7.38 * *$ & 0.38 & 0.37 & 0.14 & $0.24 *$ & $0.23 * *$ \\
\hline Tester $\times \mathrm{E}$ & 3 & 707.24 & $1,615,406.40 * *$ & $16.42 * *$ & 0.11 & 0.04 & 0.17 & 0.26 & 0.17 \\
\hline Line $\times$ tester $\times \mathrm{E}$ & 33 & 1008.00 & $1,006,232.20 *$ & $6.46 *$ & 0.42 & 0.34 & 0.12 & 0.21 & 0.10 \\
\hline Pooled error & 100 & 1365.29 & $669,902.70$ & 3.92 & 0.33 & 0.29 & 0.15 & 0.14 & 0.11 \\
\hline
\end{tabular}

$*, * *, * * *$ Significant at $0.05,0.01$ and 0.001 probability levels, respectively

${ }^{\mathrm{a}}$ Ear aspect visual scores on scale of $1-5$, where 1 = clean uniformly filled ears and $5=$ poorly filled ear with signs of rot

${ }^{\mathrm{b}}$ Plant aspect, scored on scale of $1-5$, where $1=\operatorname{good}$ phenotypic appeal and $5=$ poor phenotypic appeal

${ }^{\mathrm{c}}$ Southern corn rust scored on scale of $1-5$, where $1=$ no rust and $5=$ severe rust

${ }^{\mathrm{d}}$ Streak virus scored on scale of $1-5$, where $1=$ highly resistant to streak and $5=$ highly susceptible to streak

${ }^{\mathrm{e}}$ Southern corn leaf blight scored on scale of $1-5$, where $1=$ no blight and $5=$ severe blight 
Table 6 Estimates of general combining ability (GCA) and specific combing ability (SCA) effects of 12 yellow endosperm exotic maize inbred lines for aflatoxin accumulation averaged for 2 years across Ikenne and Ibadan

\begin{tabular}{|c|c|c|c|c|c|}
\hline \multirow[t]{2}{*}{ Line } & \multicolumn{2}{|c|}{ Aflatoxin $^{\mathrm{a}} \operatorname{Ln}(\mathrm{y}+1)$ with } & \multirow[t]{2}{*}{ GCA } & \multicolumn{2}{|l|}{ SCA with } \\
\hline & IITATZI1383 & IITATZI1394 & & IITATZI1383 & IITATZI1394 \\
\hline A6 & 3.54 & 3.64 & 0.28 & -0.33 & 0.33 \\
\hline CML287 & 4.04 & 3.63 & $0.52 *$ & -0.07 & 0.07 \\
\hline CML348 & 3.93 & 3.65 & 0.48 & -0.14 & 0.14 \\
\hline $\mathrm{Hi} 27$ & 3.01 & 2.31 & $-0.65^{*}$ & 0.08 & -0.08 \\
\hline $\mathrm{Ki} 3$ & 6.23 & 4.54 & $2.07 * * *$ & $0.56^{*}$ & $-0.56^{*}$ \\
\hline Mp420 & 2.96 & 2.20 & $-0.73^{*}$ & 0.11 & -0.11 \\
\hline Mp705 & 4.26 & 2.53 & 0.09 & $0.59 *$ & $-0.59 *$ \\
\hline Mp715 & 3.56 & 2.40 & -0.33 & 0.31 & -0.31 \\
\hline Mp717 & 3.09 & 2.45 & $-0.54^{*}$ & 0.04 & -0.04 \\
\hline Mp719 & 2.84 & 3.14 & -0.32 & -0.43 & 0.43 \\
\hline CN298 & 3.24 & 2.69 & -0.35 & 0.01 & -0.01 \\
\hline NC334 & 2.31 & 3.24 & $-0.53 *$ & $-0.74 * *$ & $0.74 * *$ \\
\hline Mean & 3.58 & 3.04 & 0.0 & 0.0 & 0.0 \\
\hline LSD & 2.20 & 1.54 & 0.57 & 0.70 & 0.70 \\
\hline
\end{tabular}

$*, * *, * * *$ Significant at $0.05,0.01$ and 0.001 probability levels, respectively

${ }^{\mathrm{a}}$ Plot means for aflatoxin concentration were transformed $\left(\mathrm{Ln}[\mathrm{y}+1]\right.$, where $\mathrm{y}=$ concentration of aflatoxin $\mathrm{ng} \mathrm{g}^{-1}$ in a sample) before statistical analysis

Table 7 Estimates of general combining ability (GCA) and specific combing ability (SCA) effects of 12 yellow endosperm exotic maize inbred lines for grain yield averaged for 2 years across Ikenne and Ibadan

\begin{tabular}{|c|c|c|c|c|c|c|}
\hline \multirow[t]{2}{*}{ Line } & \multicolumn{3}{|c|}{ Grain yield $\left(\mathrm{kg} \mathrm{ha}^{-1}\right)$ with } & \multicolumn{2}{|l|}{ SCA with } & \multirow[t]{2}{*}{ Heterotic group } \\
\hline & IITATZI1383 & IITATZI1394 & GCA & IITATZI1383 & IITATZI1394 & \\
\hline A6 & 3051 & 4405 & 257 & $-525^{*}$ & $525 *$ & IITATZI1383 \\
\hline CML287 & 4382 & 4256 & $848 * *$ & 215 & -215 & IITATZI1394 \\
\hline CML348 & 3786 & 3980 & $412 *$ & 54 & -54 & IITATZI1394 \\
\hline $\mathrm{Hi} 27$ & 2981 & 3734 & -113 & -225 & 225 & IITATZI1383 \\
\hline Ki3 & 3740 & 4253 & $526^{*}$ & -105 & 105 & IITATZI1383 \\
\hline Mp420 & 1660 & 1530 & $-1876 * *$ & 216 & -216 & IITATZI1394 \\
\hline Mp705 & 2523 & 2734 & $-843 * *$ & 46 & -46 & IITATZI1394 \\
\hline Mp715 & 3597 & 3563 & 109 & 168 & -168 & IITATZI1394 \\
\hline Mp717 & 3136 & 3453 & -176 & -8 & 8 & IITATZI1383 \\
\hline Mp719 & 3167 & 3698 & -38 & -114 & 114 & IITATZI1383 \\
\hline NC298 & 3619 & 3917 & 298 & 2 & -2 & IITATZI1394 \\
\hline NC334 & 4190 & 3943 & $596^{*}$ & 275 & -275 & IITATZI1394 \\
\hline Mean & 3319.3 & 3622.2 & 0.0 & 0.0 & 0.0 & \\
\hline LSD & 1636.2 & 1775.6 & 540.6 & 230.2 & 230.2 & \\
\hline
\end{tabular}

*, **Significant at 0.05 and 0.01 probability levels, respectively

grain yield. Inbreds CML287 and Ki3 exhibited significant positive GCA effects for both aflatoxin and grain yield (Tables 6,7). A total of 12 testcrosses involving A6, CML287, CML348, Mp719, and NC334 with tester IITATZI1383 and Hi27, Ki3, Mp420, Mp705, Mp715, Mp717 and NC298 with 
tester IITATZI1394 had negative SCA effects for aflatoxin accumulation (Table 6). Eleven of the 12 testcrosses involving CML287, CML348, Mp420, Mp705, Mp715, CN298 and NC334 with IITATZI1383 and Hi27, Ki3, Mp717 and Mp719 with IITATZI1394 had positive but not significant SCA effects for grain yield with only one testcross, A6 $\times$ IITATZI1394, having significant positive SCA effects (Table 7).

Among the 12 lines, Mp715, NC298 and NC334 had negative GCA effects for aflatoxin accumulation and positive GCA for grain yield, but the effects were significant only for NC334. Six testcrosses involving CML287, CML348 and NC334 with tester IITATZI1383 and Hi27, Ki3, and Mp717 with tester IITATZI1394 had non-significant negative SCA effects for aflatoxin accumulation and positive SCA effects for grain yield (Tables 6, 7).

Heterotic affinities of 12 yellow exotic inbred lines

The combining ability effects of grain yield of the 12 yellow aflatoxin resistant inbred lines in combination with the two adapted aflatoxin resistant testers were used as the basis for classifying the exotic lines into heterotic groups. Seven of the 12 exotic inbred lines exhibiting positive SCA effects with IITATZI1383 and negative SCA effects with IITATZI1394 were placed into the IITATZI1394 heterotic group (Table 7). The other five inbred lines showing positive SCA effects with IITATZI1394 and negative SCA effects with IITATZI1383 were placed into the IITATZI1383 heterotic group (Table 7).

Aflatoxin accumulation and yield performance of selected white and yellow testcrosses

White and yellow testcrosses were ranked for top 10 and bottom 10 based on their yield performance. Mean aflatoxin accumulation of the selected white hybrids ranged from $4 \mathrm{ng} \mathrm{g}^{-1}$ for Mp711 $\times$ IITATZI1191 to $1011 \mathrm{ng} \mathrm{g}^{-1}$ for CML247 $\times$ IITATZI1191 producing the fourth highest grain yield $\left(5331 \mathrm{~kg} \mathrm{ha}^{-1}\right)$. The top five hybrids in this set produced $32 \%$ to $61 \%$ more grain yield than Oba Super 1, four of the five top testcrosses accumulated more aflatoxin than Oba Super 1 (15 $\mathrm{ng} \mathrm{g}^{-1}$ ) (Table 8). Surprisingly, most of the bottom 10 hybrids in this set had relatively low levels of aflatoxin accumulation.
The mean aflatoxin accumulation of selected yellow hybrids ranged from $8 \mathrm{ng} \mathrm{g}^{-1}$ for Mp420 $\times$ IITATZI1394 to $93 \mathrm{ng} \mathrm{g}^{-1}$ for Ki3 $\times$ IITATZI1394. Oba Super 2 had relatively low aflatoxin accumulation (23 $\mathrm{ng} \mathrm{g}^{-1}$ ) and had grain yield of $4346 \mathrm{~kg} \mathrm{ha}^{-1}$. All the top performing testcrosses in this set had grain yield comparable to Oba Super 2. Oba Super 2 produced $2 \%$ to $16 \%$ more grain yield than eight of the top 10 testcrosses. Nearly all the top 10 yellow testcrosses accumulated relatively low levels of aflatoxin (Table 8).

\section{Discussion}

Several inoculation methods have been used to evaluate maize lines for aflatoxin resistance. In the current study, a highly toxigenic A. flavus strain was used for inoculating the maize field trials by dispersing non-viable grains of sorghum coated with spores of the fungus onto the soil surface. The inoculation technique allowed the applied toxigenic strain to dominate the treated fields and then infect the developing and maturing maize ears in a natural way via air currents and/or insects. Injecting of inoculum through silk channels (Zummo and Scott 1989), puncturing developing maize kernels with pin bars of side needles ears of maize (Windham and Williams 2007), and injection of spore suspensions under the husks of developing ears (Scott and Zummo 1988; Menkir et al. 2008; Willcox et al. 2013) are techniques commonly used in studies to examine resistance of maize germplasm to both fungal infection and aflatoxin accumulation. Aflatoxin resistance in lines based on tight husk cover and grain structure are bypassed when these three artificial inoculation methods directly introduce inoculum on the infection court under the husk (Brown et al. 1993). Adoption of the inoculation technique reported in the current study allowed classifying maize germplasm into resistant or susceptible categories using a natural, non-damaging inoculation technique. However, care must be taken to ensure that the toxigenic strain is applied at the right growth stage of maize and right amount to ensure appropriate dominance in the treated field.

Melchinger and Gumber (1998) recommended the use of elite genotypes selected from well-established heterotic groups as testers to evaluate the heterotic responses of new sets of germplasm. In each of the two 


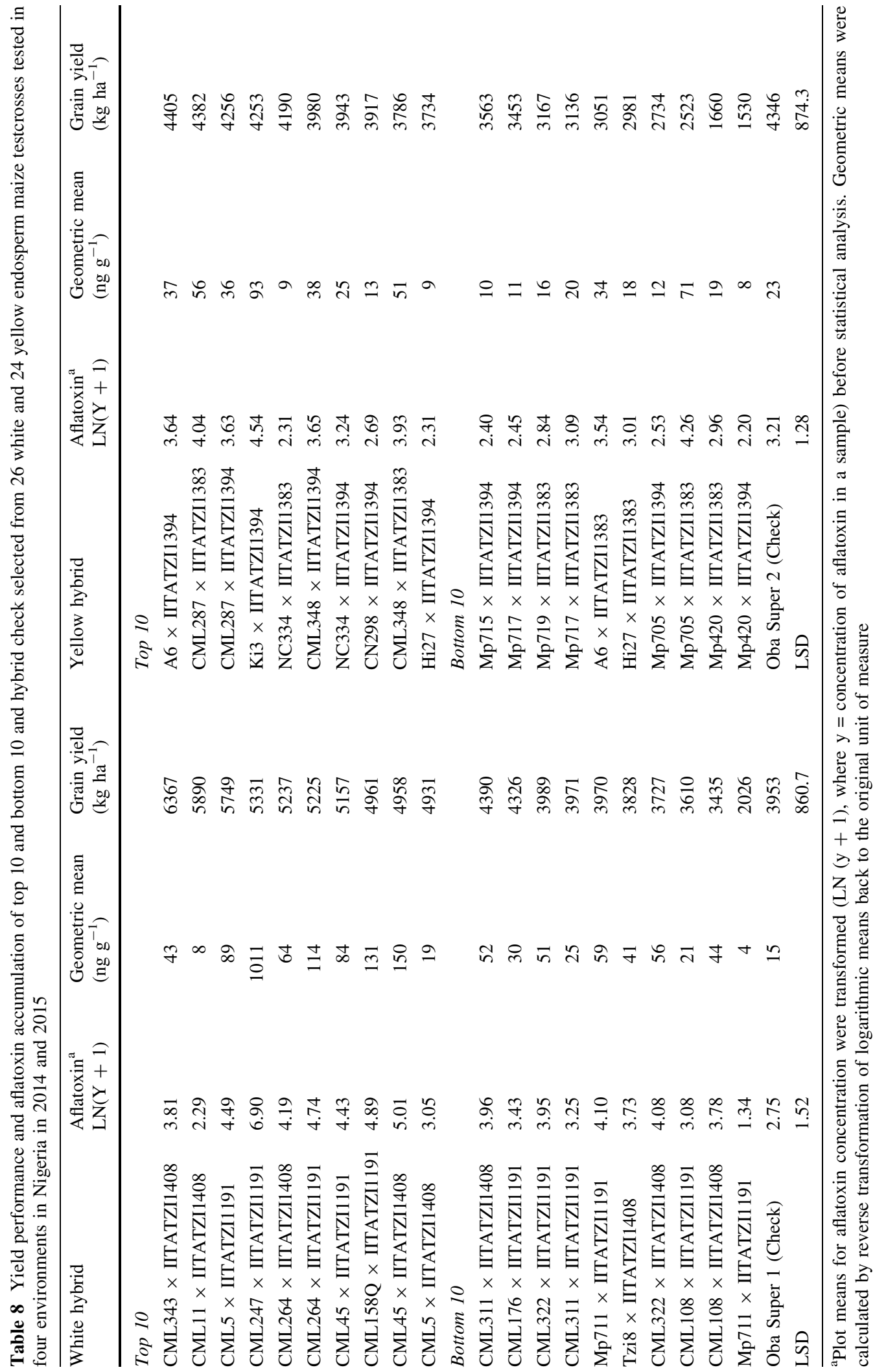


trials in this study, we used two aflatoxin resistant inbred lines bred and adapted to WCA as testers to evaluate the combining ability of 13 white and 12 yellow endosperm exotic inbred lines and to determine their heterotic affinities for yield and resistance to aflatoxin accumulation under field conditions. The adapted testers in both trials exhibited contrasting GCA effects for aflatoxin resistance. The ranking of exotic inbred lines with the complementary adapted testers represent the heterotic responses of the introduced aflatoxin resistant inbred lines and assisted the identification of those with good combining ability for resistance to aflatoxin and grain yield as potential candidates for introgression into our adapted germplasm. Only one introduced yellow endosperm inbred line (NC334) had significant negative GCA effect for resistance to aflatoxin accumulation and significant positive GCA effects for grain yield, suggesting that this line can combine well with other adapted aflatoxin resistant inbred lines and could serve as source of novel alleles for resistance to aflatoxin and high yield potential at the same time. Furthermore, this inbred could be crossed with elite inbreds related to IITATZI1383 tester to generate promising hybrids for aflatoxin accumulation resistance and grain yield. Two white (CML176, and Mp711) and three yellow (Hi27, Mp420 and Mp717) inbred lines with significant negative GCA effects for aflatoxin could be sources of genes for resistance to aflatoxin accumulation. CML5, CML264, CML11, CML343, CML287, CML348, NC334 and Ki3, with significant and positive GCA effects for grain yield, can be targeted for improving productivity in adapted maize inbred lines.

Four inbred lines (Mp420, Mp717, CML176, and Hi27) with good levels of resistance to aflatoxin accumulation identified in this study were previously reported to accumulate low aflatoxin levels under varying environments (Warburton and Williams 2014; Williams et al. 2015) in the US. The heterotic groups identified in this study can help maize breeders to exploit exotic aflatoxin resistant lines as parents of backcross populations that will be sources of new inbred lines with much higher levels of resistance to aflatoxin accumulation in tropical maize germplasm. The significant differences observed among testcrosses for aflatoxin accumulation, grain yield and other desirable agronomic traits indicated the presence of genetic differences in performance among the lines across environments. The significant line $\times$ tester interaction for aflatoxin accumulation and grain yield in the first trial and for grain yield in the second trial suggested that the adapted aflatoxin resistant testers either ranked the introduced lines differently or the magnitude of the differences among the exotic lines were different, which is one of the main features of ideal testers (Russell 1961). The non-significant line $\times$ tester $\times$ environment interaction in the second trial involving yellow testcrosses in this study suggests consistency of aflatoxin accumulation in grains of the hybrids evaluated across test environments.

In a model with fixed effects, Kang (1994) suggested the use of the ratio of GCA to SCA sums of squares to determine their relative importance. We found that GCA of lines accounted for most of the variation in aflatoxin accumulation and grain yield among testcrosses, suggesting that these traits were conditioned mainly by genes with additive effects. However, the significant line $\times$ tester sums of squares of both white and yellow endosperm testcrosses in the two trials for grain yield indicated that non-additive gene action also contributed to this trait in this set of testcrosses. Our results for aflatoxin accumulation is consistent with reports in other studies (Darrah et al. 1987; Gardner et al. 1987; Liang et al. 2006; Warburton and Williams 2014) who found that additive gene action was more important than nonadditive gene action in controlling aflatoxin resistance in maize. Similarly, Liang et al. (2006) and Ozimati et al. (2014) found additive gene action to be more important than non-additive gene action in controlling resistance to A. flavus accumulation in ground-nuts. These results suggested that selection for resistance to aflatoxin accumulation should be effective in early generations.

Some lines in the two trials generated hybrids that combined resistance to aflatoxin accumulation with appreciable grain yields, suggesting that the exotic lines contain favourable alleles for both traits not present in the testers (Menkir and Ayodele 2005). Thus, 11 testcrosses involving CML108, CML158Q and CML322 with tester IITATZI1191, CML11 and CML176 with tester IITATZI1408, CML287, CML348 and NC334 with tester IITATZI1383, and Ki3, Hi27, and Mp717 with tester IITATZI1394 were found with consistent negative SCA effects for aflatoxin accumulation and positive SCA effects for grain yield. Elite inbred lines from the same heterotic 
group involved in these testcrosses can be crossed to complementary inbred lines from another heterotic group to develop productive aflatoxin resistant hybrids broadly adapted to the lowland tropics. The testcrosses showed good levels of resistance to aflatoxin with acceptable ear and plant aspect scores as well as resistance to the three major foliar diseases (MSV, leaf blight, leaf rust) prevalent in the lowlands of WCA. The commercial hybrids checks, Oba Super 1 and Oba Super 2, included in the two independent trials, demonstrated some levels of resistance to aflatoxin accumulation across test environments. The two hybrid checks were competitive or better than some of the selected top 10 hybrids in each trail for both low aflatoxin accumulation and high grain yield. Among the selected hybrids, four yellow (CML287 $\times$ IITATZI1383, NC334 $\times$ IITATZI1383, Ki3 $\times$ IITATZI1394, CML348 $\times$ IITATZI1383) and one white (CML11 $\times$ IITATZI11408) endosperm testcrosses combined negative SCA effects for aflatoxin with positive SCA effects for grain yield. These hybrids may be crossed to the corresponding adapted testers to develop backcross populations for generating new inbred lines with better resistance to aflatoxin accumulation.

\section{Conclusions}

In conclusion, the non-damaging and natural inoculation technique reported in the current study allowed separating exotic maize inbred lines into resistant or susceptible categories. Our study classified the aflatoxin resistant exotic white and yellow endosperm maize inbred lines into heterotic groups. Only one yellow inbred line was found to display significantly good GCA for resistance to aflatoxin accumulation and grain yield. Four inbred lines with white and six with yellow endosperm were found to be good sources of alleles for resistance to aflatoxin. Five white and six of yellow endosperm testcrosses were found to be good specific combiners for resistance to aflatoxin accumulation and grain yield. Four of the six yellow and only one of the five white testcrosses were found to accumulate low levels of aflatoxin. The introduced lines with good GCA effects for resistance to aflatoxin accumulation can now be used for developing backcrosses to generate new inbred lines with higher levels of resistance to aflatoxin that can be used as parents of high-yielding hybrids with higher levels of resistance to aflatoxin production.

Acknowledgements The authors gratefully acknowledge the significant support of Dr. Wende Mengesha, Mrs. Olubunmi Bossey and IITA field technicians at Ibadan and Ikenne experimental stations in Nigeria. The authors thank John Fellers and Allen Oppong for thoughtful review and excellent suggestions for the manuscript. This work was supported by the United States Department of Agriculture and the United States Agency for International Development joint Feed the Future program, project "Genetic resistance to Aspergillus flavus and aflatoxin in maize", agreement 58-0210-3-012.

Open Access This article is distributed under the terms of the Creative Commons Attribution 4.0 International License (http:// creativecommons.org/licenses/by/4.0/), which permits unrestricted use, distribution, and reproduction in any medium, provided you give appropriate credit to the original author(s) and the source, provide a link to the Creative Commons license, and indicate if changes were made.

\section{References}

Adebayo AM, Menkir A, Blay E, Gracen V, Danquah E (2017) Combining ability and heterosis of elite drought-tolerant maize inbred lines evaluated in diverse environments of lowland tropics. Euphytica. https://doi.org/10.1007/ s10681-017-1840-5

Atehnkeng J, Ojiambo PS, Ikotun T, Sikora RA, Cotty PJ, Bandyopadhyay R (2008a) Evaluation of atoxigenic isolates of Aspergillus flavus as potential biocontrol agents for aflatoxin in maize. Food Addit Contam 25:1266-1273

Atehnkeng J, Ojiambo PS, Donner M, Ikotun T, Sikora RA, Cotty PJ, Bandyopadhyay R (2008b) Distribution and toxigenicity of Aspergillus species isolated from maize kernels from three agro-ecological zones in Nigeria. Int $\mathrm{J}$ Food Microbiol 122:74-84

Atehnkeng J, Donner M, Ojiambo PS, Ikotun B, Augusto J, Cotty PJ, Bandyopadhyay R (2016) Environmental distribution and genetic diversity of vegetative compatibility groups determine biocontrol strategies to mitigate aflatoxin contamination of maize by Aspergillus flavus. Microb Biotechnol 9:75-88

Bandyopadhyay R, Ortega-Beltran A, Akande A, Mutegi C, Atehnkeng J, Kaptoge L, Senghor AL, Adhikari BN, Cotty PJ (2016) Biological control of aflatoxins in Africa: current status and potential challenges in the face of climate change. World Mycotoxin J 9:771-789

Bankole S, Schollenberger M, Drochner W (2006) Mycotoxins in food systems in Sub Saharan Africa. Rev Mycotoxin Res 22:163-169

Betrán JF, Bhatnagar S, Isakeit T, Odvody G, Mayfield K (2006) Aflatoxin accumulation and associated traits in QPM maize inbreds and their testcrosses. Euphytica 152:247-257

Brooks TD, Williams WP, Windham GL, Willcox MC, Abbas HK (2005) Quantitative trait loci contributing resistance to 
aflatoxin accumulation in maize inbred Mp313E. Crop Sci 45:171-174

Brown RL, Cotty PJ, Cleveland TE, Widstrom NW (1993) Living maize embryo influences accumulation of aflatoxin in maize kernels. J Food Prot 56:967-971

Brown RL, Cleveland TE, Payne GA, Woloshuk CP, Campbell KW, White DG (1995) Determination of resistance to aflatoxin production in maize kernels and detection of fungal colonization using an Aspergillus flavus transformant expressing Escherichia coli b-glucuronidase. Phytopathology 85:983-989

Brown RL, Chen ZY, Cleveland TE, Russin JS (1999) Advances in the development of host resistance in corn to aflatoxin contamination by Aspergillus flavus. Phytopathology 89:113-117

Brown RL, Williams WP, Windham GL, Menkir A, Chen ZY (2016) Evaluation of African-bred maize germplasm lines for resistance to aflatoxin accumulation. Argon J 24:1-10. https://doi.org/10.3390/agronomy6020024

Busboom KN, White DG (2004) Inheritance of resistance to aflatoxin production and Aspergillus ear rot of corn from the cross of inbreds B73 and Oh516. Phytopathology 94:1101-1115

Campbell KW, Hamblin AM, White DG (1997) Inheritance of resistance to aflatoxin production in the cross between corn inbreds B73 and L31. Phytopathology 87:1144-1147

Charmley LL, Trenholm HL, Preluskey DB, Rosenberg A (1995) Economic losses and decontamination. Nat Toxins 3:199-203

Cochran WG, Cox GM (1960) Experimental designs. Wiley, New York

Cotty PJ, Cardwell KF (1999) Divergence of West African and North American communities of Aspergillus section Flavi. Appl Environ Microbiol 65:2264-2266

Darrah LI, Lillehoj EB, Zuber MS, Scott GE, Thompson D, West DR, Widstrom NW, Fortnum BA (1987) Inheritance of aflatoxin B1 levels in maize kernels under modified natural inoculation with Aspergillus flavus. Crop Sci 27:869-872

Dhliwayo T, Pixley K, Menkir A, Warburton M (2009) Combining ability, genetic distances, and heterosis among elite CIMMYT and IITA tropical maize inbred lines. Crop Sci 49:1201-1210

Eschandi CR, Hallauer AR (1996) Evaluation of US corn belt and adapted tropical maize cultivars and their diallel crosses. Maydica 41:317-324

Gardner CAC, Darrah LL, Zuber MS, William JR (1987) Genetic control of aflatoxin production in maize. Plant Dis 71:426-429

Gong YY, Turner PC, Hall AJ, Wild CP (2008) Aflatoxin exposure and impaired child growth in West Africa: an unexplored international public health burden? In: Leslie JF, Bandyopadhyay R, Visconti A (eds) Mycotoxins. Detection methods, management, public health and agricultural trade. CABI, Oxfordshire, pp 53-65

Gorman DP, Kang MS, Cleveland T, Hutchinson RL (1992) Combining ability for resistance to field aflatoxin accumulation in maize grain. Plant Breed 109:292-303

Hennigen MR, Dick T (1995) Incidence and abundance of mycotoxins in maize in Rio Grande do Sul, Brazil. Food Addit Contam 12:677-681
Holland JB, Goodman MM (1995) Combining ability of tropical maize accessions with US germplasm. Crop Sci 35:767-773

Kang MS (1994) Applied quantitative genetics. M.S. Kang Publication, Baton Rouge

Lewis L, Onsongo M, Njapau H, Schurz-Rogers H, Luber G, Kieszak S, Nyamongo J, Backer L, Dahiye A, Misore A, DeCock K, Rubin C (2005) Aflatoxin contamination of commercial maize products during an outbreak of acute aflatoxicosis in Eastern and Central Kenya. Environ Health Perspect 113:1762-1767

Liang XQ, Luo M, Guo BO (2006) Resistance mechanisms to Aspergillus flavus infection and aflatoxin contamination in peanuts (Arachis hypogaea). Plant Pathol J 5:115-124

Matacic C (2016) Fungal toxins are poisoning Africa's children, says new report. Science 18 Feb 2016

Melchinger AE, Gumber RK (1998) Overview of heterosis and heterotic groups in agronomic crops. In: Lamkey KR, Staub JE (eds) Concept and breeding of heterosis in crop plants. CSSA SP Publication No 25, Madison, pp 29-44

Mellon JE, Cotty PJ, Dowd MK (2007) Aspergillus flavus hydrolases: their roles in pathogenesis and substrate utilization. Appl Microbiol Biotechnol 77:497-504

Menkir A, Ayodele M (2005) Genetic analysis of resistance of grey leaf spot of midaltitude maize inbred lines. Crop Sci 45:163-170

Menkir A, Badu-Apraku B, Thè C, Adepoju A (2003) Evaluation of heterotic patterns of IITA's lowland white maize inbred lines. Maydica 48:161-170

Menkir A, Brown RL, Bandyopadhyay R, Chen ZY, Cleveland TE (2006) Africa collaborative strategy for identifying, characterizing, and developing maize germplasm with resistance to aflatoxin contamination. Mycopathologia 162:225-232

Menkir A, Brown RL, Bandyopadhyay R, Cleveland TE (2008) Registration of six tropical maize germplasm lines with resistance to aflatoxin contamination. J Plant Regist 2:246-250

Miller JO (1996) Mycotoxins. In: Cardwell KF (ed) Proceedings of the workshop on mycotoxins in food in Africa. Cotonou, Benin, pp 18-22. 6-10 Nov 1995

Nelson PT, Goodman MM (2008) Evaluation of elite CIMMYT maize inbred lines for use in temperate breeding. Crop Sci 45:85-92

Ozimati AA, Rubaihayo PR, Gibson P, Edema R, Kayondo IS, Ntare BR, Okello DK (2014) Inheritance of resistance to kernel infection by Aspergillus flavus and aflatoxin accumulation in groundnut. Afr J Crop Sci 2:51-59

Pollak LM, Torres CS, Sotomayor-Rios A (1991) Evaluation of heterotic patterns among Caribbean and tropical-temperate maize populations. Crop Sci 31:1480-1483

Probst C, Njapau H, Cotty PJ (2007) Outbreak on acute aflatoxicosis in Kenya in 2004: identification of the causal agent. Appl Environ Microbiol 73:2762-2764

Ramjee G (1996) Aflatoxin, kwashiorkor and morbidity. In: Cardwell KF (ed) Proceedings of the workshop on mycotoxins in food in Africa. Cotonou, Benin, pp 25. 6-10 Nov 1995

Russell WA (1961) A comparison of five types of testers in evaluating the relationship of stalk rot resistance in corn 
inbred lines and stalk strength of lines in hybrid combinations. Crop Sci 11:393-397

Santos MX, Miranda Filho JB (1992) Genetic potential of two Brazilian races of maize for breeding purposes. $\mathrm{J}$ Genet Breed 46:83-90

SAS Institute (2010) SAS/STAT 9.3 users guide. SAS Institute, Cary

Scott GE, Zummo N (1988) Sources of resistance in maize to kernel infection by Aspergillus flavus in field. Crop Sci 28:504-507

Singh RK, Chaudhary BD (1985) Biometrical methods in quantitative genetic analysis. Kalyani Publishers, Ludhiana

Sprague GF, Tatum LA (1942) General vs. specific combining ability in single crosses of corn. J Am Soc Agron 34:923-932

Warburton ML, Williams WP (2014) Aflatoxin resistance in maize: what have we learned lately? Adv Bot. https://doi. org/10.1155/2014/352831

Widstrom NW (1996) The aflatoxin problem with corn grain. Adv Agron 56:219-280

Willcox MC, Davis GL, Warburton ML, Windham GL, Abbas HK, Betrán JF, Holland JB, Williams WP (2013) Confirming quantitative trait loci for aflatoxin resistance from Mp313E in different genetic backgrounds. Mol Breed 32:15-26

Williams WP, Krakowsky MD, Windham GL, Balint-Kurti P, Hawkins LK, Henry WB (2008) Identifying maize germplasm with resistance to aflatoxin accumulation. Toxin Rev 27:319-345

Williams WP, Krakowsky MD, Scully BT, Brown RL, Menkir A, Warburton ML, Windham GL (2015) Identifying and developing maize germplasm with resistance to accumulation of aflatoxins. World Mycotoxin J 8:193-209

Windham GL, Williams WP (2007) A comparison of inoculation techniques for inducing aflatoxin contamination and Aspergillus flavus kernel infection on corn hybrids in the field. Phytoparasitica 35:244-252

Wu F (2004) Mycotoxin risk assessment for the purpose of setting international regulatory standards. Environ Sci Technol 38:4049-4055

Xia XC, Reif JC, Melchinger AE, Frisch M, Hoisington DA, Beck D, Pixley K, Warburton ML (2005) Genetic diversity among CIMMYT maize inbred lines investigated with SSR markers. II. Subtropical, tropical midaltitude and highland maize inbred lines and their relationships with elite U.S. and European maize. Crop Sci 45:2573-2582

Zain ME (2011) Impact of mycotoxins on humans and animals. J Saudi Chem Soc 15:129-144

Zummo N, Scott GE (1989) Evaluation of field inoculation techniques for screening maize genotypes against kernel infection by Aspergillus flavus in Mississippi. Plant Dis 73:313-316 